\title{
Sintesa Konsep Spiritual Leadership dan Islamic Leadership
}

\author{
Abi Sopyan Febrianto \\ Universitas Pendidikan Indonesia \\ abisopyan@upi.edu
}

\begin{abstract}
Abstrak
Seringkali spiritual leadership dan Islamic leadership dianggap sebagai hal yang sama, namun pada kenyataannya menggambarkan sesuatu yang berbeda. Spiritual leadership menekankan pada kualitas hubungan dan peran pemimpin dalam organisasinya, sedangkan Islamic leadership lebih berfokus kepada karakteristik diri seorang pemimpin. Penting untuk membuat artikel konseptual yang mengupas perbedaan antara keduanya dan melakukan sintesa, sehingga didapati hasil dengan konsentrasi yang lebih menyeluruh. Artikel ini mencoba melakukan sintesa terhadap teori spiritual leadership dan Islamic leadership. Hasil sistesa teori memberikan pengertian yang lebih moderat dan komprehensif.
\end{abstract}

Kata Kunci: Islamic leadership, kepemimpinan, spiritual leadership

\begin{abstract}
Spiritual leadership and Islamic leadership are considered to be the same thing frequently, but in reality illustrate differently. Spiritual leadership emphasizes the quality of relationships and the role of leaders in their organizations, while Islamic leadership focuses more on the characteristics of a leader. It is important to make a conceptual article that examines the differences between the two and synthesizes, so that the results are found with a more thorough concentration. This article attempts to synthesize spiritual leadership theory and Islamic leadership. The results of the synthesis theories give a more moderate and comprehensive understanding.
\end{abstract}

Keywords: Islamic leadership, leadership, spiritual leadership

\section{PENDAHULUAN}

Peran kepemimpinan dalam suatu organisasi merupakan hal yang fundamental. Kesuksesan suatu organisasi tidak lepas dari pengaruh kepemimpinan di dalamnya, hal ini didukung oleh pendapat Siagian (2002) yang menyatakan bahwa keberhasilan atau kegagalan organisasi ditentukan oleh kualitas kepemimpinan yang dimiliki oleh pemimpinnya. Oleh karenanya pemimpin harus senantiasa mampu bertanggungjawab atas setiap resiko yang terjadi. Dalam situasi seperti sekarang ini dibutuhkan sosok pemimpin yang mampu menghadapi perubahan secara berkesinambungan serta pemimpin yang mampu meningkatkan kesadaran bawahannya dengan memberikan dorongan cita-cita dan nilai moral yang lebih tinggi melalui pengembangan potensi dan kinerja bawahan (Herdiyanti et al, 2010). Menurut Davis (1996), tanggungjawab dari seorang pemimpin organisasi yaitu mendorong kelompok ke arah tujuan-tujuan yang bermanfaat, sehingga prestasi kerja mereka dapat meningkat.

Spiritual leadership atau kepemimpinan spiritual diamati dapat meningkatkan komitmen individu dalam suatu organisasi. Di samping itu, para individu menganggap pemimpin mereka lebih produktif secara rohani/spiritual bagi organisasi. Fry (2003) menyatakan bahwa pemimpin spiritual dapat membuat para anggota merasa puas dengan pekerjaan yang mereka lakukan. Tingkat spiritualitas pemimpin yang tinggi diperlukan karena mendorong produktivitas dan komitmen organisasional anggota yang penting bagi kelangsungan kinerja organisasi (Fry, 2003). Temuan tersebut selanjutnya membuktikan spiritual leadership memainkan peran integral dalam pengembangan pendekatan terhadap karir anggota. Baik kepemimpinan maupun keanggotaan yang memiliki spiritualitas tinggi berhubungan langsung antar satu sama lain. Hasilnya menunjukkan bahwa spiritual leadership dapat membuat para anggota memusatkan perhatian pada nilai altruistik yang membuat mereka merasa layak dan terhubung dengan anggota lainnya dalam organisasi. Penelitian terdahulu mengemukakan bahwa ketika individu mempraktikkan nilai, perilaku, dan sikap altruistik, individu akan merasa dihargai dan dipahami (Bodla et al, 2013).

Spiritual seringkali dikaitkan dengan praktekpraktek ibadah bagi seorang pemeluk agama. Dalam Islam, terdapat suatu konsep kepemimpinan yang disebut dengan Islamic leadership atau kepemimpinan Islami. Islamic leadership merupakan konsep kepemimpinan yang menawarkan suatu model kepemimpinan yang berupaya menyusun strategi tercapainya kesuksesan secara seimbang, baik dalam bisnis, keluarga, 
sosial, maupun spiritual berdasarkan tauladan kepemimpinan dan manajemen Nabi Muhammad serta semangat asmaul husna (Antonio, 2013). Seorang pemimpin dalam Islam harus memiliki kesadaran spiritual (sebagai hamba Tuhan) dan kesadaran rasional (sebagai khalifah Tuhan). Sebagai hamba Tuhan, manusia menjadi makhluk yang setia dan selalu melakukan perintah serta menjauhi larangan Tuhan. Sebagai khalifah Tuhan, manusia menjadi makhluk yang sukses di dunia melalui pengetahuan (Nuruddin, 2011). Islamic leadership memiliki dampak positif terhadap anggota maupun organisasi, terbukti bahwa praktek Islamic leadership yang dilakukan mampu meningkatkan kinerja individu (Wijayanti dan Wadji, 2012). Kepemimpinan dalam perspektif Islam adalah amanah, merupakan kontrak psikologis antara pemimpin dan anggotanya yang menyatakan bahwa pemimpin akan mengupayakan yang terbaik untuk membimbing, melindungi serta memperlakukan mereka secara adil (Hidayat, 2012).

Menurut Khavari dalam Hidayat (2012), karakteristik kecerdasan spiritual terdiri dari tiga aspek, diantaranya: (1) kecerdasan spiritual sebagai hubungan spiritual-keagamaan yaitu hubungan vertikal antara manusia dan Allah yang terkait dengan ibadah ritual; (2) kecerdasan spiritual sebagai hubungan sosial-keagamaan yaitu sikap sosial yang menekankan pada kebersamaan serta kesejahteraan sosial; (3) kecerdasan spiritual sebagai etika sosial yang menekankan pada kepatuhan terhadap etika dan moralitas terhadap sesama manusia. Banyak persepsi bahwa spiritual leadership dan Islamic leadership merupakan hal yang sama, hanya berbeda dalam sudut pandang. Spiritual leadership merupakan penamaan yang berasal dari barat sedangkan Islamic leadership berasal dari negara dengan penduduk muslim namun menunjukkan hakekat dan esensi yang sama. Beberapa pendapat menyatakan bahwa spiritualitas tidak bisa disamakan dengan agama. Lebih jauh spiritualitas mendorong ketenangan batin untuk diri-sendiri dan lingkungan sekitar (Lawrence, 1999). Berangkat dari fenomena tersebut sehingga perlu adanya kajian mendalam tentang spiritual leadership dan Islamic leadership. Selanjutnya perlu dilakukan sistesa dari teori spiritual leadership dan Islamic leadership sehingga menghasilkan teori baru.

Artikel ini bertujuan memperkaya literatur akademik tentang kepemimpinan, khususnya spiritual leadership dan Islamic leadership. Penulis mencoba melakukan sintesa terhadap dua teori kepemimpinan yang menghasilkan teori baru tentang Islamic spiritual leadership yang diambil dari teori Islamic leadership Antonio (2013) \& Nuruddin (2011) dan spiritual leadership dari teori
Fry (2003). Alasan yang mendasari penulis melakukan sintesa dari teori Islamic leadership dan spiritual leadership dikarenakan konsentrasi dari teori Islamic leadership dan spiritual leadership yang masing-masing berbeda satu sama lain. Islamic leadership ditinjau dari literatur-literatur terdahulu dirancang berdasarkan perintah Allah dalam Al-Quran dan hadits dengan merepresentasikan profil kepemimpinan ideal dari Nabi Muhammad yang bertujuan membentuk pemimpin yang memiliki kepribadian seperti halnya Nabi Muhammad, sehingga Islamic leadership lebih berfokus kepada karakteristik diri seorang pemimpin. Sedangkan spiritual leadership lebih berkonsentrasi kepada peran dan hubungan yang mendalam dari pemimpin kepada anggotanya. Spiritual leadership lebih menekankan kepada kualitas hubungan dan peran pemimpin dalam organisasinya dibandingkan dengan fokus pengembangan diri dari pemimpin tersebut. Sehingga dengan dilakukannya sistesa dari kedua teori tersebut, diharapkan mampu membentuk konstruk yang konsentrasi secara menyeluruh.

\section{PEMBAHASAN}

Penelitian empiris tentang spiritual leadership dan Islamic leadership telah banyak dilakukan. Seringkali spiritual leadership dan Islamic leadership difungsikan sebagai variabel independen yang bertujuan menguji pengaruh terhadap variabel dependennya. Hasil penelitian oleh Afsar et al (2016) membuktikan bahwa spiritual leadership berpengaruh terhadap spiritualitas di tempat kerja, motivasi intrinsik dan perilaku pro-lingkungan pada karyawan. Begitupun dengan hasil penelitian oleh Zachary (2013) yang membuktikan bahwa altruistic love yang merupakan salah satu indikator dari spiritual leadership (Fry, 2003) berpengaruh terhadap komitmen afektif dan komitmen normatif. Hasil penelitian tentang Islamic leadership terbukti mampu berpengaruh terhadap kinerja (Syamsuddin, 2014; Harahap, 2016; Wijayanti dan Wadji, 2012), motivasi intrinsik dan kesejahteraan anggota (Kuklyte, 2017). Terdapat hasil penelitian yang menggunakan variabel Islamic spiritual leadership yang didapat dari hasil sintesa teori spiritual leadership dan Islamic leadership (Febrianto et al, 2019) yang membuktikan bahwa Islamic spiritual leadership berpengaruh terhadap motivasi intrinsik dan komitmen organisasional. Namun pada penelitian tersebut tidak dibahas secara terperinci mengenai sintesa yang dilakukan, hanya sebatas pengujian variabel hasil sintesa terhadap variabel lain.

Pada artikel ini, sintesa terhadap teori spiritual leadership dan Islamic leadership dilakukan dengan cara melakukan penjabaran terhadap masingmasing teori merujuk dari pendapat tokoh yang digunakan. Selanjutnya dilakukan pencocokan 
terhadap masing-masing indikator teori yang dirasa memiliki karakteristik serta esensi yang sama, lalu dikembangkan melalui definisi dari masing-masing indikator dan definisi teori dari hasil sintesa. Sehingga didapatkan definisi yang lebih kompleks dari hasil sintesa yang dilakukan.

\section{A. Spiritual Leadership}

Menurut Louis W Fry (2003) spiritual leadership (kepemimpinan spiritual) merupakan paradigma yang muncul dalam konteks yang lebih luas dari spiritualitas tempat kerja dan dirancang untuk menciptakan organisasi pembelajaran yang termotivasi secara intrinsik. Spiritual leadership terdiri dari nilai-nilai, sikap, dan perilaku yang diperlukan untuk secara intrinsik memotivasi diri sendiri dan memenuhi kebutuhan mendasar untuk kesejahteraan spiritual.

Urgensi spiritual leadership menurut Fry (2003) yaitu:

1. Menciptakan visi dimana para pemimpin dan para anggotanya merasakan suatu panggilan sehingga hidup mereka memiliki tujuan, makna, serta mampu merasakan perbedaan dari sebelumnya.

2. Menetapkan budaya organisasi berdasarkan nilai-nilai altruistik di mana para pemimpin dan para anggotanya memiliki rasa keanggotaan, merasa dipahami, dihargai, dan memiliki kepedulian yang tulus, perhatian, serta penghargaan.

Fry (2003) menggambarkan bahwa sumber spiritual leadership adalah praktik kehidupan batin seperti menghabiskan waktu di alam, berdoa, praktik keagamaan, meditasi, membaca, yoga, atau menulis. Praktik kehidupan batin secara positif mempengaruhi kepemimpinan rohani melalui pengembangan harapan dan keyakinan dalam visi pelayanan yang transenden kepada para pemangku kepentingan. Harapan dan keyakinan dalam visi yang jelas dan memikat menghasilkan rasa panggilan (sense of calling), hal tersebut merupakan bagian dari kesejahteraan spiritual (spiritual wellbeing) yang memberi seseorang rasa untuk membuat perbedaan dan menjadikan kehidupan seseorang memiliki makna tersendiri. Spiritual leadership juga mengharuskan budaya organisasi didasarkan pada nilai-nilai altruistik. Pemimpin harus memodelkan nilai-nilai ini melalui sikap dan perilaku yang menciptakan rasa keanggotaan, yang merupakan bagian dari kesejahteraan spiritual sehingga memberikan anggota rasa untuk dipahami dan dihargai. Dimensi spiritual leadership dan proses memuaskan kebutuhan spiritual kemudian secara positif mempengaruhi hasil individu dan organisasi yang terdiri dari Triple Bottom Line.
Perbedaan yang terdapat pada spiritual leadership menurut Fry (2003) yaitu antara memimpin (Personal Spiritual Leadership) dan kepemimpinan (Organizational Spiritual Leadership). Personal spiritual leadership (PSL) berkaitan dengan pengembangan personal yang lebih menekankan pada pengetahuan individu, keterampilan, dan kemampuan yang terkait dengan peran kepemimpinan formal, serta pengaruh pemimpin pada anggotanya. Sedangkan organizational spiritual leadership (OSL) berkaitan dengan pengembangan organisasi yang fokus pada proses pengaruh sosial kolektif yang melibatkan semua orang dan memungkinkan sekelompok orang untuk bekerja bersama dengan cara yang bermakna. Organizational spiritual leadership menekankan pendekatan yang kurang berpusat pada pemimpin, berfokus pada melibatkan semua anggota kelompok untuk memenuhi kebutuhan spiritual, meningkatkan komitmen, dan kinerja organisasi. Dengan cara ini, setiap orang dianggap sebagai pemimpin. Pemimpin formal dan informal akan muncul dari interaksi para anggota pada organisasi yang menerapkan spiritual leadership.

Menurut Fry (2003), spiritual leadership dapat diukur menggunakan triple buttom line, yaitu visi (vision), cinta altruistik (altruistic love), harapan \& keyakinan (hope \& faith). Visi mengacu pada gambaran masa depan dengan disertai dorongan implisit maupun eksplisit tentang mengapa orang harus berusaha untuk mencapai masa depan tersebut. Dalam memotivasi perubahan, visi melayani tiga fungsi penting dengan memperjelas arah perubahan umum, menyederhanakan keputusan yang lebih terperinci, dan membantu mengoordinasikan anggota kelompok dengan cepat dan efisien. Selain itu, visi yang menarik memberi energi kepada para anggota, memberi makna untuk bekerja, menumbuhkan komitmen, dan menetapkan standar keunggulan. Dalam memobilisasi anggota, visi harus memiliki daya tarik yang luas, menentukan tujuan dan perjalanan organisasi, mencerminkan cita-cita yang tinggi, dan mendorong harapan dan keyakinan.

Altruistic love atau cinta altruistik didefinisikan sebagai rasa keutuhan, harmoni, dan kesejahteraan yang dihasilkan melalui kepedulian, perhatian, dan penghargaan untuk diri sendiri dan orang lain. Terdapat banyak manfaat emosional dan psikologis dari memisahkan antara perhatian dan kepedulian terhadap orang lain dengan kebutuhan yang merupakan inti dari memberi dan menerima. Ilmu tentang psikologi telah mulai mempelajari dan memastikan bahwa cinta memiliki kekuatan untuk mengatasi pengaruh negatif dari emosi yang merusak seperti dendam, kemarahan, kekhawatiran, dan ketakutan. Cinta altruistik mendefinisikan seperangkat nilai kunci, asumsi, pemahaman dan 
cara berpikir yang dianggap benar secara moral yang dibagikan oleh anggota kelompok dan diajarkan kepada anggota baru. Para pemimpin mewujudkan dan mematuhi nilai-nilai ini melalui sikap dan perilaku sehari-hari.

Harapan adalah keinginan untuk dipenuhi dan keyakinan menambah kepastian harapan tersebut. Secara bersama-sama, harapan dan keyakinan merupakan keyakinan kuat terhadap sesuatu yang tidak ada buktinya. Hal ini didasarkan pada nilai, sikap, dan perilaku yang menunjukkan kepastian dan kepercayaan mutlak bahwa apa yang diinginkan dan diharapkan akan terjadi. Individu dengan harapan dan keyakinan memiliki visi yang ingin mereka capai, dan bagaimana mencapainya. Mereka akan senantiasa siap dalam menghadapi pertentangan, kesulitan, dan penderitaan untuk mencapai tujuan mereka. Harapan dan keyakinan juga merupakan sumber untuk keyakinan bahwa visi, baik pribadi atau organisasi, akan terpenuhi. Dalam tindakannya, harapan dan keyakinan ibarat sesuatu yang memiliki dua komponen penting, yaitu kemenangan (visi) dan sukacita yang mempersiapkan sesuatu itu sendiri. Kedua komponen tersebut merupakan elemen penting dari harapan dan keyakinan untuk menghasilkan upaya yang diperlukan untuk mengejar visi tersebut.

\section{B. Islamic Leadership}

Islamic leadership merupakan suatu konsep kepemimpinan yang didasarkan pada kepemimpinan Rasulullah SAW dengan menawarkan suatu model kepemimpinan yang berupaya menyusun strategi tercapainya kesuksesan secara seimbang baik dalam bisnis, keluarga, sosial, maupun spiritual, berdasarkan suri tauladan kepemimpinan dan manajemen Nabi Muhammad serta semangat asmaul husna (Antonio, 2013).

Seorang pemimpin Islam harus mampu memiliki kesadaran spiritual (hamba Allah) dan kesadaran rasional (khalifah Allah). Sebagai hamba Allah, manusia dituntut menjadi makhluk yang setia seperti yang diperintahkan oleh Allah. Sebagai khalifah Allah, manusia menjadi makhluk yang sukses di dunia ini melalui perolehan pengetahuan (Nuruddin, 2013). Integrasi keunggulan rasional (khalifah Allah) serta keseimbangan emosional dan spiritual (hamba Allah) pada gilirannya akan melahirkan jiwa dan keyakinan yang mendorong sikap dan perilaku yang dicintai oleh Allah. Islamic leadership harus mampu menyatukan kesadaran ilahi (al-rabbaniy) dan kesadaran rasional (al'ilmiy). Orang yang memiliki pengetahuan, mampu membaca, memahami, dan memanfaatkan dengan benar realitas kehidupan mampu merasakan ketakutan (al-khasyyah) kepada Allah, mereka adalah orang-orang yang dianggap sebagai pemimpin yang cerdas dan berkualitas sesuai yang tertera dalam Al-Quran. Pada intinya, pemimpin Islami adalah mereka yang memiliki pengetahuan yang terintegrasi dengan profesinya disertai ketakutan terus menerus kepada Allah (Marbun 2013).

Menurut Antonio (2013) terdapat empat sasaran utama yang hendak dicapai melalui model Islamic leadership. Pertama, terbentuknya pribadi yang paripurna (insan kamil) yang bersumber pada ajaran tauhid dan memiliki integritas yang tinggi. Suri tauladan ini tercermin dari sifat shiddiq Rasulullah SAW. Menurut asal katanya, shiddiq memiliki arti selalu melandaskan pada kebenaran atau keimanan yang benar (tauhid). Keimanan yang benar ini akan melahirkan sikap, prilaku dan tindakan yang benar pula. Seseorang yang mengamalkan sifat ini akan dikenal sebagai pribadi yang memiliki integritas tinggi.

Kedua, terbentuknya interpersonal capital yaitu hubungan yang harmonis antar sesama manusia dalam berbagai lingkungan sosial berdasarkan rasa saling percaya (mutual trust). Suri tauladan ini tercermin dari sifat amanah Rasulullah SAW, yang mana kata amanah tersebut secara harfiah berarti terpercaya dan merupakan modal utama untuk membangun social trust.

Ketiga, munculnya kemampuan teknis dan manajerial melalui dorongan untuk menjadi pribadi yang kompeten dengan menguasai ilmu pengetahuan, keterampilan teknis, serta menjunjung tinggi profesionalisme dan good corporate governance. Technical competence seperti ini dibentuk dengan menguraikan unsur-unsur pembentuk sifat fathanah dari Rasulullah SAW.

Keempat, leadership wisdom atau kearifan dan seni dalam kepemimpinan. Hal ini dapat dicapai dengan mengoptimalkan kemampuan komunikasi dalam memimpin dengan visi, misi dan pendelegasian wewenang yang jelas serta tim kerja yang solid. Hal ini tercermin dari penerapan sifat tabligh Rasululah SAW terhadap sahabat-sahabat yang merupakan kolega, asisten, staf, mitra, serta tim kerja dalam merealisasikan tujuan dan sasaran perjuangan beliau.

Menurut Antonio (2013), pengukuran dari Islamic leadership yang sesuai dengan Al-Quran dan Hadits Rasulullah SAW yaitu shiddiq, amanah, fathanah, dan tabligh. Shiddiq berarti benar dalam berkata dan baik dalam perbuatan. Dasar dari shiddiq dalam Al-Quran (2014) terdapat pada QS. Al-Ahzab ayat 71: "Hai orang-orang yang beriman, bertakwalah kamu kepada Allah dan katakanlah perkataan yang benar, niscaya Allah memperbaiki bagimu amalanamalanmu dan mengampuni bagimu dosa-dosamu" dan dalam hadits dari Ibnu Mas'ud ra, Rasulullah bersabda: "Sesungguhnya shiddiq itu menuntut kepada kebaikan, dan kebaikan itu akan 
membawanya ke dalam surga" (HR. Bukhari dalam Abdul Baqi, 2012).

Amanah diartikan sebagai seseorang yang apabila berjanji maka akan ditepati dan apabila dititipkan sesuatu maka dia akan menjaganya dengan baik. Dasar dari amanah dalam Al-Quran (2014) terdapat pada QS. An-Nisa ayat 58: "Sesungguhnya Allah menyuruh kamu untuk menyampaikan amanah kepada yang berhal menerimanya, dan (menyuruh kamu) apabila menetapkan hukum diantara manusia supaya kamu menetapkan dengan adil" dan hadits dari Abu Hurairah, Rasulullah bersabda: "Tandatanda orang munafiq ada tiga; jika berbicara berbohong, jika berjanji ia ingkar, dan jika diberi amanah dia berkhianat (HR. Muttafaqun 'Alaih dalam Abdul Baqi, 2012).

Fathanah di sini diartikan sebagai pribadi yang pandai serta memiliki wawasan yang luas. Dasar dari fathanah telah termaktub dalam hadits. Dari Abu Hurairah, Rasulullah bersabda: "Jika suatu urusan diserahkan kepada yag bukan ahlinya, maka tunggu lah kehancurannya" (HR. Bukhari no. 6015).

Tabligh merupakan kemampuan berkomunikasi dengan lemah lembuh dan menyampaikan perkataan yang mudah dipahami. Dasar dari tabligh telah ada dalam Al-Quran (2014) pada QS. Al-A'raf ayat 55: "Berdoalah kepada Tuhanmu dengan berendah diri dan suara yang lemah lembut, sungguh Allah tidak menyukai orang-orang yang melampaui batas" dan QS Al-Isra ayat 28: "Dan jika kamu berpaling dari mereka untuk memperoleh rahmat dari Tuhannya yang kau harapkan, maka katakanlah kepada mereka ucapan yang mudah".

Dimensi Islamic leadership menurut Nuruddin (2011) ialah piety (Taqwa), moral (Akhlaq), dan quality (Itqan). Piety atau taqwa diartikan sebagai pribadi yang menyadari selamanya akan kebesaran Tuhan, hal ini digambarkan dalam beberapa karakteristik, yaitu 'ittimaniyyah (kepercayaan), 'adalah (keadilan), ikhlas (keikhlasan), amanah (kejujuran), syukur (bersyukur), dan shujaah (keberanian). Moral atau akhlaq diartikan sebagai pribadi yang memiliki akhlak yang sesuai dengan aqidah Islam, hal ini digambarkan dalam beberapa karakteristik, yaitu ihtimam (kepedulian), ta'awun/musa'adah (kerjasama), mulathofah (adab), tawadhu'/wadho'ah (rendah hati), tasaamuh (toleransi), dan ihtiram/riayah (menghormati). Quality atau itqan diartikan sebagai pribadi yang memiliki kesadaran yang tinggi terhadap perbaikan pada diri sendiri, hal ini digambarkan dalam beberapa karakteristik, yaitu syiddah al maf'ul (efektivitas), iqtidah/fa'aliyyah (efisiensi), tajdid/ihdath (inovasi), intidzam (kedisiplinan), iltizam/lida' (komitmen), dan ta'allum (pembelajar).
Pada artikel ini dilakukan sistesa terhadap variabel Islamic leadership oleh Antonio (2013) dan Nuruddin (2011) dan variabel spiritual leadership oleh Fry (2003). Dibangun pola sistesa dari masingmasing indikator Islamic leadership dan spiritual leadership yang selanjutnya dianalisis kesamaan esensi dari masing-masing indikator tersebut. Dari teori spiritual leadership oleh Fry (vision, altruistic love, hope \& faith) dan Islamic leadership oleh Antonio (shiddiq, amanah, fathanah, \& tabligh) dan Nuruddin (moral, piety, \& quality), dibentuk sistesa dari masing-masing indikator teori tersebut.

Tabligh dalam teori Islamic leadership Antonio (2013) diartikan sebagai individu yang mampu berkomunikasi dengan lemah lembut dan menyampaikan perkataan yang mudah dipahami. Tujuan dari sifat tabligh yaitu leadership wisdom atau kearifan dan seni dalam kepemimpinan. Hal tersebut dicapai dengan mengoptimalkan kemampuan komunikasi dalam memimpin dengan visi, misi, pendelegasian wewenang yang jelas, serta tim kerja yang solid. Tabligh dikaitkan dengan indikator vision (visi) dalam teori spiritual leadership Fry yang dimaknai sebagai visi yang mengacu pada gambaran masa depan dan menjelaskan mengapa masa depan tersebut harus dicapai. Visi mampu memberikan energi, makna dalam bekerja, dan membentuk komitmen anggota. Visi harus mampu menggambarkan tujuan, cita-cita tertinggi, dan mendorong harapan serta keyakinan. Dari hasil sistesa yang disusun, peneliti menyimpulkan bahwa tabligh merupakan makna lebih luas dari vision (visi).

Altruistic love dalam teori spiritual leadership oleh Fry diartikan sebagai rasa keutuhan, harmoni dan kesejahteraan yang bersumber dari kepedulian, perhatian dan penghargaan untuk diri sendiri dan orang lain. Cinta altruistik mendefinisikan seperangkat nilai kunci, asumsi, pemahaman dan cara berpikir yang dianggap benar secara moral yang dibagikan oleh anggota kelompok dan diajarkan kepada anggota baru. Altruistik love mendorong kepercayaan/loyalitas, rasa syukur, integritas, kejujuran, keberanian, rendah hati, kebaikan, belas kasih, dan kesabaran pada diri seseorang. Makna tersebut dikaitkan dengan moral pada teori Islamic spiritual menurut Nuruddin dan shiddiq menurut Antonio. Moral atau akhlaq digambarkan sebagai sikap dan perilaku yang beradab, penuh kepedulian, mampu bekerjasama, rendah hati, toleran, dan menghormati orang lain. Sedangkan shiddiq diartikan sebagai sifat seorang individu yang benar dalam berkata dan baik dalam perbuatan. Sifat shiddiq tersebut akan melahirkan pribadi yang paripurna (insan kamil) yang bersumber pada ajaran tauhid dan memiliki integritas tinggi. Dari hubungan dan kesamaan tersebut, peneliti menyimpulkan bahwa altruistic 
love, moral, dan shiddiq merupakan indikator yang memiliki kesamaan dan mampu digabungkan dalam penelitian ini. Indikator ini disebut altruistik dikarenakan memiliki arti yang mampu menggambarkan ketiga indikator tersebut.

Hope (harapan) \& faith (keyakinan) dalam teori spiritual leadership Fry yaitu harapan yang merupakan keinginan untuk dipenuhi dan keyakinan menambah kepastian dari suatu harapan. Harapan dan keyakinan tersebut dimaknai sebagai keyakinan kuat terhadap sesuatu yang belum ada buktinya. Harapan dan keyakinan ini didasarkan pada nilai, sikap, dan perilaku yang menunjukkan kepastian dan kepercayaan mutlak bahwa visi, baik pribadi maupun organisasi akan terpenuhi. Penulis menyimpulkan bahwa indikator harapan dan keyakinan tersebut tidak memiliki karakteristik yang sama dan mirip dengan indikator lainnya pada Islamic leadership baik menurut Antonio maupun Nuruddin. Indikator ini disebut dengan harapan dan keyakinan karena memiliki makna yang lebih terfokus.

Fathanah yaitu pandai dalam teori Islamic leadership Antonio dimaknai sebagai sifat yang akan melahirkan pribadi yang memiliki kemampuan teknis dan manajerial melalui dorongan untuk menjadi pribadi yang kompeten dengan menguasai ilmu pengetahuan, keterampilan teknis, serta menjunjung tinggi profesionalisme dan good corporate governance. Fathanah dikaitkan dengan indikator quality (itqan) dari teori Islamic leadership Nuruddin dikarenakan memiliki makna yang mirip. Quality atau itqan oleh Nuruddin dimaknai sebagai kesadaran terhadap perbaikan diri dan digambarkan sebagai individu yang efektif, efisien, inovatif, disiplin, berkomitmen, dan pembelajar. Dua indikator tersebut digabungkan dan disebut sebagai fathanah karena memiliki makna yang lebih mendalam dibandingkan dengan quality.

Piety atau ketaqwaan merupakan indikator dari Islamic leadership Nuruddin, diartikan sebagai individu yang menyadari selamanya akan kebesaran Allah, hal tersebut didasarkan pada kepercayaan, keadilan, keikhlasan, kejujuran, dan keberanian. Ketaqwaan ini dikaitkan dengan indikator amanah karena memiliki kemiripan makna. Amanah diartikan yaitu terpercaya, merupakan modal utama untuk membangun social trust. Sifat ini bertujuan membentuk hubungan yang harmonis antar sesama manusia (interpersonal capital) dalam berbagai lingkungan sosial berdasarkan rasa saling percaya (mutual trust). Oleh peneliti, indikator ini disebut dengan ketaqwaan karena indikator tersebut memiliki makna lebih luas dibandingkan dengan amanah. Rangkuman sintesa pada penelitian ini dianalogikan pada Gambar 1 berikut:

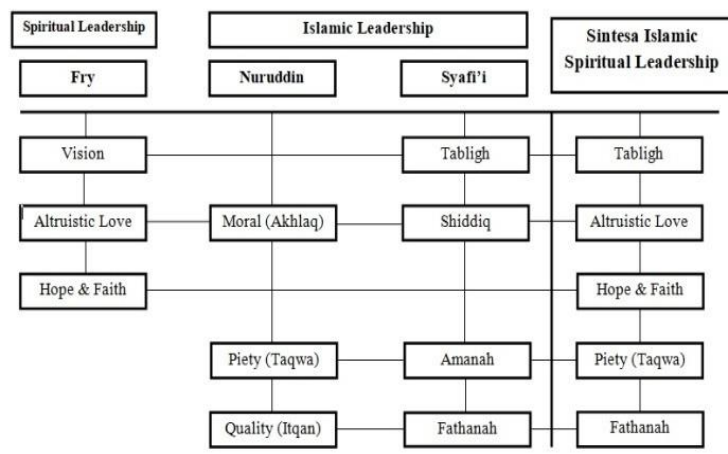

Gambar 1. Rangkuman Sintesa Islamic Spiritual Leadership

Sumber: Hasil Sintesa Teori, 2019

Dari penjabaran pada paragraf sebelumnya, maka dibentuk perspektif baru dari hasil sistesa teori Islamic leadership dan spiritual leadership yang disebut dengan variabel Islamic spiritual leadership yang didefinisikan sebagai suatu konsep kepemimpinan yang bertujuan menciptakan leadership wisdom atau seni dalam memimpin, dengan mengoptimalkan kemampuan komunikasi, memiliki rasa kepedulian, perhatian, dan penghargaan kepada diri sendiri dan orang lain, mempunyai keyakinan kuat terhadap sesuatu yang belum ada buktinya dengan semangat untuk menjadi pribadi yang kompeten melalui penguasaan ilmu pengetahuan, keterampilan teknis dan manajerial, menjunjung tinggi profesionalisme, serta senantiasa menyadari akan kebesaran Tuhan untuk mencapai kesuksesan secara seimbang.

Selanjutnya Islamic spiritual leadership diukur menggunakan lima indikator yang telah disintesa dari pendapat Fry (2003), Antonio (2013) dan Nuruddin (2011) yaitu tabligh, altruistik, harapan dan keyakinan, ketaqwaan, serta fathanah. Tabligh yang dimaksud yaitu mampu berkomunikasi dengan lemah lembuh dan menyampaikan perkataan yang mudah dipahami. Bertujuan untuk mempraktekkan leadership wisdom atau seni dalam memimpin, dengan cara mengoptimalkan kemampuan komunikasi dalam mendefinisikan tujuan, langkah, dan pendelegasian wewenang yang jelas agar terbentuk tim kerja yang solid. Altruistik yang disimpulkan pada artikel ini diartikan sebagai rasa keutuhan, harmoni, dan kesejahteraan yang bersumber dari kepedulian, perhatian, penghargaan untuk diri sendiri dan orang lain, memiliki kekuatan untuk mengatasi pengaruh dari emosi yang masuk, serta baik dalam perbuatan dan benar dalam perkataan. Harapan \& keyakinan yang dimaksud diartikan sebagai harapan yang merupakan keinginan untuk dipenuhi dan keyakinan menambah kepastian dari suatu harapan, hal tersebut didefinisikan sebagai keyakinan kuat terhadap sesuatu yang tidak ada buktinya yang didasarkan pada nilai, sikap, dan perilaku yang mempercayai secara mutlak terhadap tercapainya tujuan, serta 
meyakini bahwa akan selalu ada balasan atas suatu perbuatan. Ketaqwaan yang dmaksudkan diartikan sebagai individu yang menyadari selamanya akan kebesaran Tuhan, hal ini mampu membuat individu tersebut dapat dipercaya dalam segala hal, selalu berusaha menepati janji dan adil dalam bertindak. Fathanah diartikan pandai, merupakan suatu kepribadian yang akan melahirkan individu yang memiliki kemampuan teknis dan manajerial melalui dorongan untuk menjadi pribadi yang kompeten dengan menguasai ilmu pengetahuan, keterampilan teknis, bertindak inovatif, serta menjunjung tinggi profesionalisme dan good corporate governance.

\section{SIMPULAN DAN SARAN}

\section{Simpulan}

Islamic leadership dan spiritual leadership memiliki konsentrasi dan fokus yang berbeda. Islamic leadership bertujuan membentuk pemimpin yang memiliki kepribadian seperti Nabi Muhammad SAW, sehingga lebih berfokus kepada karakteristik diri seorang pemimpin. Sedangkan spiritual leadership lebih berkonsentrasi kepada peran dan hubungan yang mendalam dari pemimpin kepada anggotanya, sehingga menekankan kepada kualitas hubungan dan peran pemimpin dalam organisasinya. Melakukan sintesa terhadap kedua teori tersebut sangat penting untuk pengembangan literature akademik. Dengan dilakukannya sistesa dari kedua teori tersebut, diharapkan mampu membentuk konstruk yang terkonsentrasi secara menyeluruh.

\section{Saran}

Penelitian selanjutnya dapat mengimplementasikan pengaruh Islamic spiritual leadership terhadap berbagai variabel seperti halnya motivasi, komitmen, kepuasan maupun kinerja, serta pada berbagai objek penelitian baik lembaga profit maupun non-profit. Menarik untuk bisa melakukan penelitian terkait pada lembaga atau organisasi berbasis agama non-Islam, sehingga mampu dianalisis hasil dari penelitian tersebut sebagai kontribusi untuk pengembangan literature akademik berupa penelitian empiris.

\section{DAFTAR PUSTAKA}

Abdul Baqi, Muhammad Fu'ad. 2012. Al-Lu'lu' wal Marjan: Shahih Bukhari Muslim. Semarang: PT. Pustaka Riski Putra.

Afsar, B., Y, Badir., and U.S, Kiani. 2016. Linking spiritual leadership and employee proenvironmental behavior: The influence of workplace spirituality, intrinsic motivation, and environmental passion.
Al Quran Terjemahan dan Tajwid. 2014. Lajnah Pentahsinan Mushaf Al Quran. Kementerian Agama Republik Indonesia. Bandung. Sygma.

Antonio, S. 2013. Ensiklopedia PROLM Prophetic Leadership and Management Wisdom. Jakarta: Tazkia Publishing.

Bodla, M. A., H. Ali., and R. Q. Danish. 2013. Role of Spiritual Leaders in Enhancing Employee's Performance. Journal Basic and Applied Scientific Research, Vol. 3, No. 3, 117-122.

Davis, K and B. W. William. 1996. Human Resources and Personal Management. Fifth Edition. Irwin McGraw-Hill. United States of America.

Febrianto, Abi S., Noermijati, Himmiyatul A. J. Juwita., and Sana A. Alashkam. 2019. The Influence of Psychological Empowerment and Islamic Spiritual Leadership On Organizational Commitments and Intrinsic Motivation. Jurnal Aplikasi Manajemen, Vol. 17, No. 3, Pages 381-390.

Fry, L. W. 2003. Toward a Theory of Spiritual Leadership. The Leadership Quarterly, 14. 693727.

Harahap, S. (2016). Pengaruh Kepemimpinan Islami dan Motivasi Kerja Terhadap Kinerja Karyawan Pada PT. Bank Syariah Mandiri, Tbk Kantor Cabang Pembantu Sukaramai Medan. Human Falah, Vol. 3, No. 2, pp. 253270.

Herdiyanti, R. S., M. Setiawan., and U. Nimran. 2010. Pengaruh Gaya Kepemimpinan Terhadap Kinerja dan Kepuasan Kerja Karyawan. Indonesia Journal of Social and Humanity Study, Vol. 13, No. 4, 528-536.

Hidayat, W. 2012. Islamic Leadership a Spiritual Leadership Paradigm. [On line]. From: https://www.kompasiana.com/liwaganteng/551 04c2aa333110237ba80d0/islamic-leadership-aspiritual-leadership-paradigm

Kuklyte, J. 2017. Islamic Leadership and Workplace Deviance: What Are The Interactions? Balkan Journal of Social Sciences / Balkan Sosyal Bilimler Dergisi. (presented in the ICOMEP 2017).

Lawrence, J. F. 1999. Spirit at Work: The search for deeper meaning in the workplace. [On line]. From: https://hbswk.hbs.edu/archive/spirit-atwork-the-search-for-deeper-meaning-in-theworkplace

Marbun, D. S. (2013). Attributions and requirements of Islamic leadership. 
Management Research Review, Vol. 36, No. 4, pp. 379-387.

Nuruddin, A. 2011. Sumber Daya Syariah. Paper Presented at The Medan: Forum Riset Perbankan Syariah, Bank Indonesia.

Siagian, S. P. 2002. Manajemen Sumber Daya Manusia. PT. Bumi Aksara. Jakarta.

Syamsuddin. (2014). Penerapan Kepemimpinan Islam dan Pengaruhnya terhadap Kinerja Pengelola Ksp Syariah di Kabupaten Wajo dan Kabupaten Enrekang. Jurnal Aplikasi Manajemen, Vol. 12 No. 4, pp. 1-7.

Wijayanti, R. and F. Wadji. 2012. Pengaruh Kepemimpinan Islami, Motivasi dan Kepuasan Kerja Terhadap Kinerja Karyawan dengan Lama Kerja sebagai Variabel Moderating. Jurnal Ekonomi Manajemen Sumber Daya, 13 (2), 108-115.

Zachary, G. W. 2013. Spiritual Leadership: Investigating The Effects of Altruistic Love On Organizational Commitment. International Journal of Arts \& Sciences, 6 (2), 767-819. 